Journal of Social Sciences 8 (2): 126-134, 2012

ISSN 1549-3652

(C) 2012 Science Publications

\title{
Transformation or Transgression? Institutional Habitus andWorking Class Student Identity
}

\author{
Tina Byrom and Nic Lightfoot \\ School of Education, College of Arts and Humanities, \\ Nottingham Trent, University Clifton Lane Nottingham NG11 8NS
}

\begin{abstract}
Problem statement: Whilst evidence continues to highlight disparity in Higher Education (HE) participation rates across social groups, there continues to be small numbers of young people from social groups 4-7 choosing to go to university. However, university experience varies across the different social groups and differing social positions appear to influence the higher education institution students apply to and secure places in. Whilst this raises questions concerning the potential for social mobility, it also points to issues concerning how young people, who are first generation students, cope with the emerging theoretical distance between themselves and their families, once they begin to embrace university life (an issue that can negatively impact on student retention and achievement). A body of literature deals with such issues within institutions that are considered to be elite, but there is little that focuses specifically on students within post-1992 institutions-institutions that tend to be viewed as less prestigious. Approach: This research attempts to fill this apparent gap by exploring the ways in which first generation students within a post-1992 institution understand and explain their identity transformation as they progress through their undergraduate programme. A qualitative approach was used to gather data. A questionnaire was administered to a Year 1 undergraduate cohort (comprising 120 students) in a post-1992 institution. This approach was used to establish a sample of first generation students. All students who identified themselves as first generation students were emailed and invited to take part in the research. Semi-structured interviews with 10 students took place. Results: Results would suggest that when students continue to live at home whilst studying, their identity transformation or transgression from a family based habitus is not as pronounced as for students who leave home and live on campus. Conclusion/Recommendations: This research has potential to inform H.E policy on transition processes and retention and contributes to a recognition beginning in the literature that not all first generation students see higher education as transgression.
\end{abstract}

Key words: Higher Education (HE), Office of National Statistics (ONS), Index of Multiple Deprivation (IMD), widening participation, identity transformation

\section{INTRODUCTION}

Following political attention to widening participation, the UK higher education landscape has expanded to meet increased student demand (Blanden and Machin, 2004). Similar patterns of expansion have been observed internationally (Agasisti, 2009). The growth in student numbers brings a theoretically diverse student population, within which social position appears to play a determining factor in the type of higher education an individual student, would experience (Archer and Hutchings, 2000; Platt, 2011). In the UK, there are perceptions of a binary distinction between research intensive institutions (identified as being elite or 'top' institutions) and those formed post
1992 that place an emphasis on teaching which are often perceived as being less prestigious. The consequence of this divide results in institutions becoming synonymous with particular social demographics where there are large socio-economic and ethnic gaps in the likelihood of attending an $\mathrm{HE}$ institution with high status (as measured by research intensiveness)' (Chowdry et al., 2008). The Higher Education Statistics Agency data (http://www.hesa.ac.uk/index.php/content/category/2/3 2/141/ for details of participation rates) also indicates that institutions perceived as being elite attract the majority of their students from the higher social groups as illustrated in Figure 1 (this figure represents

a sample of UK HE institutions).

Corresponding Author: Tina Byrom, School of Education, College of Arts and Humanities, Nottingham Trent, University Clifton Lane Nottingham NG11 8NS Tel: +44 (0)115 8483499

Fax: +44 (0)1158486626 


\section{J. Social Sci., 8 (2): 126-134, 2012}

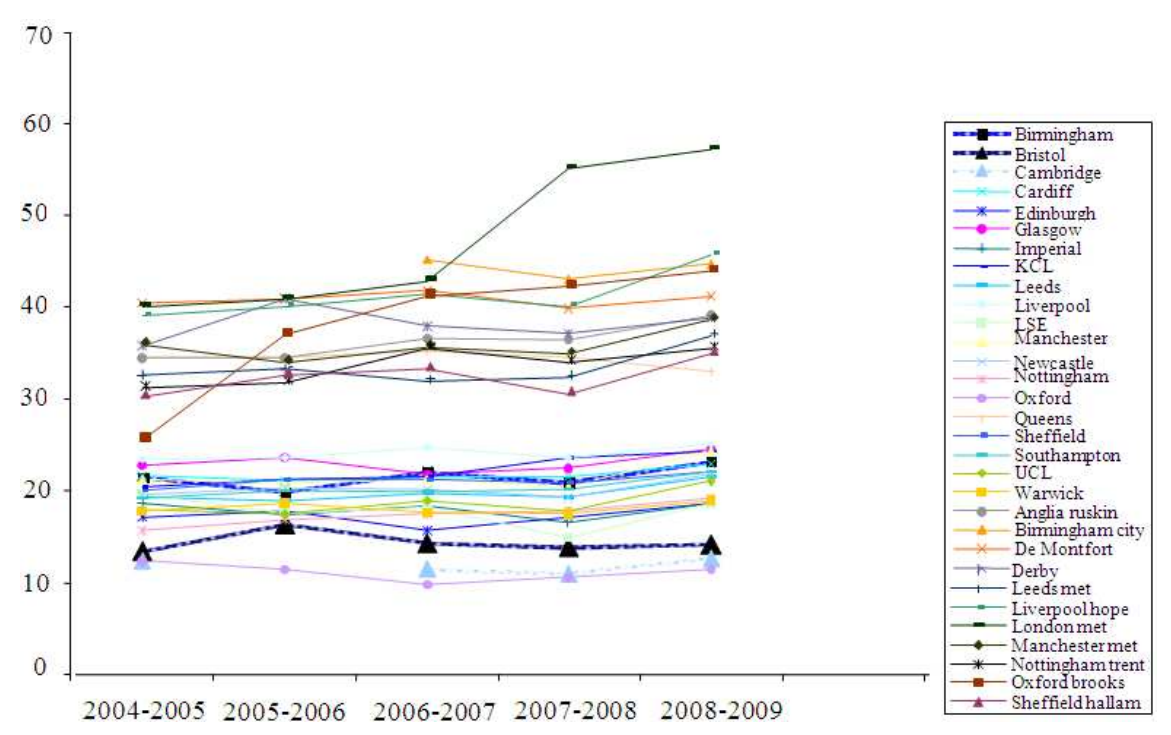

Fig. 1: Russell group Vs. Post-1992 universities: Participation rates of SEG 4-7

The difference therefore between the two groups would indicate that there is less social difference, or the occupation of different social spaces (Bourdieu, 1990b) amongst the student body at a post-1992 institution when compared with traditional universities that attract fewer students from social groups 4-7. Thus the composition of HE appears to reflect wider social inequalities with higher percentages of middle class students continuing to secure places in traditional (elite) universities and working class students (who are also predominantly first generation students) entering post1992 institutions (Archer and Hutchings, 2000). Whilst habitus (Bourdieu, 1997) is one of the most contested of Bourdieu's theoretical tools (Reay, 2004) it does go some way in helping to explain the ways in which first generation students establish a fit within the HE field. The process of establishing a fit (both academically and socially) has been identified as more problematic for first generation students given the lack of familiarity with the field. That is, some young people are more appropriately equipped, through their class based habitus, to be aligned or already 'adjusted to the immanent demands of the game' (Bourdieu, 1990a). Adjusting to the game requires first generation students to deal with what is unfamiliar, or rather becoming conversant with the particular doxa inherent within education. In a Bourdieuian analysis, this requires habitus transformation or the acceptance that people from the same background may have 'more than one identifiable habitus' (Nash, 1999) and are therefore pre-disposed to establish a fit earlier than others from the same social position. This goes some way in explaining why some young people from non-traditional backgrounds do go into higher education and the ways in which a habitus can be adapted through its exposure to specific experiences. Writing Bourdieu and Wacquant (1992) emphasise this point by stating that although habitus is a product of history (and therefore predictable to some extent) it is also ...an open system of dispositions that is constantly subjected to experiences and therefore constantly affected by them in a way that either reinforces or modifies its structures. (Bourdieu and Wacquant, 1992)

Reed-Danahay (2005) elaborates on this and argues for both a primary and secondary habitus: where the primary habitus is constructed and maintained through family interactions and connections and the secondary habitus is developed through enculturation within educational experiences. This perspective offers some flexibility in interpretation of habitus and allows insights into the ways in which first generation students attempt to establish a sense of fit within a field with which they are not as familiar as their middle class peers.

One way in which first generation students establish a fit within the field of education, is to occupy spaces in institutions that have failed to acquire the same perceived status as traditional universities (Archer et al., 2003; Leathwood, 2006; McNay, 2006). Whilst this is not intended to be a foregrounding of a deficit model of HE participation it does illustrate the way in which the 'classed policy regime' (Ball, 2003) structures the experiences of those not fully conversant with the rules of the game (Bourdieu, 1990a). The particular class based logic (Bourdieu, 1986) at play in university choice determines the types of institutions first generation students consider. This is partly due to their habitus, 
which has driven the choice process in the first place, but also a manifestation of the need to 'fulfil a social function of legitimating social differences' (Bourdieu, 1986): Differences that result in the inequitable distribution of social groups across the HE sector.

Whilst a number of possible explanations for this social group distribution centre on academic and social fit (Bourdieu, 1984; Rose, 1989; Holloway, 1997; Mahony and Zmroczek, 1997; Parr, 1997; Skeggs, 1997; Reay 2001; Walkerdine et al., 2001) there is little research that focuses on the influence that institutions have on the identity formation of widening participation students (The terms widening participation and first generation student are used interchangeably to represent students who were first in their family to go to university, given the strong correlation found between the two) in post-1992 institutions. In particular, there is currently insufficient information about the nature of their transformation or 'transgression' (Bourdieu, 1999) from their family based habitus. This research seeks to fill this apparent gap by focusing on identity trans/formation. Taking a Bourdieuian perspective it explores the result of a habitus that theoretically enters a field with which it is not familiar (Reay et al., 2005). With a focus placed on the notion of habitus clive (ReedDanahay, 2005) it specifically utilizes Bourdieu's theoretical tools to ask questions about the enculturation of working class students into the middle class field of education and in particular, the ways in which the institutional habitus influences their identity transformation. With that in mind the following research questions will be addressed:

- What factors influence identity transformation of widening participation students?

- How does an evolving identity impact on the sense of belonging both within the institution and within social groups?

\section{MATERIALS AND METHODS}

Bourdieu states that ... the goal of sociology is to uncover the most deeply buried structures of the different social worlds that make up the social universe, as well as the 'mechanisms' that tend to ensure their reproduction or transformation.

Bourdieu and Clough (1996) with a focus on the idea of habitus transformation/transgression, this study, although located within a wide body of research concerning university choice, is also situated within policy discourses around widening participation in the UK. Students, who identified themselves as being the first in their family to go into higher education, across three years of an undergraduate joint honours programme, were invited to participate in the research. This provided us with a longitudinal aspect to the research in which we could consider the idea of a change in habitus over time, but also to uncover the ways in which the institution influenced the transformation or transgression of a class based habitus. Students comprised 210 in total and ranged from 18-25 in age.

The methods used within this research seek to uncover the complexities of identity transformation through the students' understandings and perceptions of how they believed they had changed as they progressed through their undergraduate course. In order to explore this issue, the following methods were used:

- Questionnaire

- E-mail communication

- Focus group discussion

- Individual interviews

The initial questionnaire was administered to the Year 1 cohort across an undergraduate joint honours education programme and was used to establish a sample for that year group. Post-codes were entered into the Office of National Statistics (ONS) web-site to obtain an Index of Multiple Deprivation (IMD) score which is based on a range of measures including housing, rates of crime, education levels, health and unemployment figures. The highest rank score is 32-248 and the lowest 1.

Post-code information was used to explore student background-and in particular whether they had come from a low-participating background (a geographical area that sends few students into HE). All students who identified themselves as first generation students were contacted by email and asked to volunteer to take part in the research. In addition, the same email was sent out to Year 2 and 3 students. Two focus group interviews and ten individual interviews were conducted.

Ethics: This research complies with the code of practice for the conduct of educational research as provided by the British Education Research Association (BERA, 2004).

Findings: Post-code data gathered from the questionnaire indicated a wide spread of social backgrounds with some appearing to illustrate lowparticipating backgrounds and others not, as illustrated in Table 1. In teasing out the complexity of student identity, three areas of influence emerged: institutional; family; peers. 
Table 1: Post-code analysis

\begin{tabular}{|c|c|c|c|}
\hline \multirow[b]{2}{*}{ IMD rank score } & \multirow[b]{2}{*}{ No. of students } & \multicolumn{2}{|c|}{ First generation studen } \\
\hline & & Yes & No \\
\hline \multicolumn{4}{|c|}{$16,-449$ (low participation } \\
\hline backgrounds) & 14 & 10 & 4 \\
\hline $6,450-12,899$ & 11 & 7 & 4 \\
\hline $12,900-19,347$ & 13 & 6 & 7 \\
\hline $19,348-32,348$ & 31 & 13 & 18 \\
\hline Total & 69 & 36 & 33 \\
\hline
\end{tabular}

It is acknowledged that these are inextricably linked and that there is an inevitable degree of overlap and blurring of boundaries between peer group, family and institution' (Reay et al., 2005). However, what came across clearly in the interview data was a sense of students being able to establish a fit within the institution because of the support networks they had outside of the university through for example, their family and friends. We now discuss these areas in relation to the question of whether the students entered into a process of transformation or transgression.

\section{RESULTS}

Results would suggest that when students continue to live at home whilst studying, their identity transformation or transgression from a family based habitus is not as pronounced as for students who leave home and live on campus.

\section{DISCUSSION}

This section provides a discussion of the findings and does this through a discussion of the post-code analysis and also using statements from the students themseleves.

The influence of geographical location: Literature highlights the tensions that can exist for first generation students as they enter the HE field (Reay et al., 2005; Archer and Hutchings, 2000). Such research focuses on students that identify themselves as first generation students and who also come under the umbrella of 'widening participation' and thus come from low participating neighbourhoods. However, post-code analysis from this data would suggest that the boundaries of what constitutes a widening participation student are somewhat blurred given the spread of first generation students across the differing IMD rank scores.

In this sample, there are 10 students from areas considered to be low participating neighbourhoods and 13 who come from areas where academic attainment has been relatively high over a period of time, many young people progress into $\mathrm{HE}$, the majority of adults have level 4 or 5 qualifications and there are low levels of unemployment. This raises important issues concerning the way/s in which students are acculturated into the HE context given that, theoretically, some will be more pre-disposed to its practices than others. The homogenisation of young people into one student identity is therefore problematic and raises issues for academics in terms of how widening participation students are integrated into university academic and social life (Lightfoot, 2009).

Whilst literature highlights the ease with which middle class students appear to make the transition into HE (Power, 2003), such analysis is based on the binary distinction between a working class and middle class identity. In addition, it is no longer possible to consider students from perceived wealthy backgrounds (as indicated by a high IMD rank score) as having a family history of $\mathrm{HE}$ as the findings from this post-code analysis would suggest. In terms of establishing a sense of fit (whether in academic or social terms), the focus of this study has therefore been placed on the fact that the students have identified themselves as first generation students and as such do not have a family history of HE. From this understanding, the research allows us to uncover the extent to which a habitus is malleable and adaptable to context (Byrom, 2009). The ways in which the students in this study established their sense of fit are represented under three themes:

- The comfort blanket of home

- Perceived acts of transgression

- Evolving identity

The comfort blanket of home: The 'cultural characteristics' (Reay et al., 2005) of a post-1992 institution have been identified as being different than those of a traditional institution (Leathwood and O'Connell, 2003). Many of the students in our study were attracted to the university given its close proximity to home, confirming literature that suggests that working class students lead localised lives (Healy, 2006). The idea that university can influence a student identity needs to be considered in light of the propensity of the students to remain in the family home. Rob, for example explained:

Because I live at home still, I had that kind of comfort blanket of when I went home, it was like that first day at school, my mum was like how was uni, 


\section{J. Social Sci., 8 (2): 126-134, 2012}

what have you done and everything like that and for me that was really nice because then I could let out and tell her how I was feeling. (Rob: Interview: 24/1/11)

Kelly also found that she needed the familiarity of her home surroundings to help her settle into university. Initially Kelly moved into halls of residence on the university campus, however found herself sharing accommodation with students who she quickly disassociated herself from: ...but it was living with really immature drunks basically-you'd get woken up, my body clock would be totally out, because they didn't shut up until 5 o'clock in the morning and then you'd sleep half the day, but then in the evening because there's no-one at lectures, you'd all be socialising so you'd never get any work done because I was up half the night because I couldn't sleep and it just didn't work. (Kelly: Interview: 23/3/11)

Kelly further emphasises the difference she perceived between herself by describing the routine she established once she moved back home:

I think it's, a lot of my friends are ones that didn't go into halls, they lived at home and obviously I lived at home from 6 months in-I moved home in the March of Year 1 and I just commuted since and a lot of people are like that so we've kind of dis, dis, what's the word, separated ourselves from the people who have really embraced themselves into university life because we'd literally come like it was at school, we'd come and do our lectures, or we might spend a couple of hours in the canteen having a chat, or spend a couple of hours in the library doing some work but then we go home and we wouldn't come again until the next lecture (Kelly: Interview: 23/3/11).

In Bourdieuian terms, Kelly has identified a theoretical distance between herself and her peers-or the occupation of differing social spaces (Bourdieu, 1998). This identification resulted in Kelly moving back home, where she was supported by her family and therefore did not have to reconcile the apparent differences she felt between herself and other students. The potential 'crisis' (Bourdieu, 1990b) or questioning of the family based habitus was therefore removed. This is further emphasised when Kelly was asked where she felt she belonged. Her response indicates a stronger pull to home:

At home. I come here twice a week and go home again. I don't really like Nottingham to be honest. I think of it like school-you have to go home afterwards. Because I live at home and maybe that's why I don't live in Nottingham and why I didn't push to live in Nottingham for longer. (Kelly: Interview: 23/3/11)
Josie also emphasises the strong pull to remain at home, but not in the same way as Kelly. Josie highlights her lack of familiarity with the HE field and the re-assurance she gained from remaining at home:

Uhm, I don't know really, it's just like, going somewhere where I don't know, don't know anyone, I don't really know what I'm doing, I'm all confused and just the whole added things, like I don't' know what the hell's going off, at least if I'm at home then at least I know some things. (Josie: Interview: 22/2/11)

Jo also gains her sense of belonging from home justifying her decision to attend a local based university on the basis that she is 'a homey kind of girl' (Jo: Interview: 22/2/11). In addition, Jo also describes how she feels supported by her family:

When I do my uni work they kind of let me have the whole of the dining room, like they'll eat and then leave me to it, my mum will cook me some food, like she was like remember to cook yourself some food, but now she'll say like there's some food in the freezer that's already cooked if you want it and they also understand why I'm up at 2 o'clock in the morning which is nice. (Jo: Interview: 22/2/11)

The sense that 'they're all in it together' comes through strongly in Jo's narrative of why she chose to stay at home, however, in relation to the key questions posed above some initial insight into our current third year students would indicate that there are some tensions between family members and their decision to go to university.

Perceived acts of transgression: Some of our students highlighted the discomfort that family members had about their decision to go to university where the 'transgression' is experienced in terms of pursuing a path that is not necessarily supported by the family. For example, Ella states that being the first in her family to go to university is:

[s] cary, a lot of emphasis is placed on how well I do, they [parents] disagree with my career choice so there is a lot of pressure to do well and prove them wrong. (Ella: e-mail communication: 10-12-10)

Rob also hinted that all was not well within his family as he went through the process of applying to university:

My dad would have liked it if I had gone straight into work, my mum would have been horrified because she would have thought well, you've got the GCSEs, you've got the A levels, it would be stupid not to go and further that even more. Where dad, I think he's quite scared of education because he didn't have a good experience whatsoever at school, like he left school at 15 , then like literally on that Monday, like he left on the 


\section{J. Social Sci., 8 (2): 126-134, 2012}

Friday and on the Monday he was in a job and he kind of has that idea that everyone should do that, there shouldn't be any academics or anything like that. (Rob: Interview: 24/1/11)

For our students, 'spatial notions of proximity and distance' (Reay et al. 2005) help us to understand the process of transformation and/or transgression that is at play during their time at university. The students in our study discuss their attempts to belong in various social positions where the stability in their own identity is disrupted through their decision to enter the HE field. For Josie, this is felt more in relation to her peer group outside of university where she feels the pressure to undertake various roles:

It's just like, I feel like I do so many different roles in my life, it's just like, I'm a student, I'm a girlfriend, I'm a sister, I'm an aunty, I'm a friend and it's like, people I'm around outside of uni, they need me more than the people inside uni so I'm like there for them more. (Josie: Interview: 22/2/11)

Importantly Josie also goes on to explain that her 'non-university' friends do not fully understand why she chose to undertake a degree course when they have made different choices, especially those who have become teenage mothers. The degree of separation Josie feels in relation to this group is expressed in her not quite knowing where she really belongs, a situation reflective of a habitus in conflict with itself, or where the primary habitus (Reed-Danahay, 2005) is protecting itself against 'crises and critical challenges' (Bourdieu 1990a) through processes of alignment and where identity re/formation takes place.

Evolving identity: Bourdieu describes the difficulties in establishing position within social fields as individuals attempt to develop an 'inherent part of belonging' (Bourdieu, 1990b). The competing tensions between what the students were leaving behind and their attempts to fit into their new contexts, is a consistent theme that emerged within our data. Josie reflects upon this as she illuminates the complex process of forming friendships as she attempted to gravitate towards similarly minded people.

I'd say at first I didn't really speak to anyone, but I didn't mind not speaking with anyone because I thought it's alright, I'll be alright by myself. But the more I spoke with anyone, the more I thought it's kind of alright kind of thing-they're all similar to me kind of thing. (Josie: Interview: 22/2/11)

Kelly also goes through the process of working out who she fits in with. Having worked for a year prior to coming to university, Kelly dissociated herself from younger and what she considered as less mature students. She firmly identifies two types of students:

There are two types of student-you've got your drunken immature students and then you've got the ones who are here to get a degree, they're not interested in anything else. The drunken immature ones tend to be younger and male, I would say but that's from whom I lived with, because the majority of people on the course are female and I don't socialise with them. The other type is older, with children, they don't' need to be a lot older, but having already worked or have a job or other responsibility where coming to university is more of a risk (Kelly: Interview: 23/3/11)

When asked who she identifies most with, Kelly responded 'definitely the older ones' (Kelly: Interview: 23/3/11) disassociating herself from students who 'basically go out and get drunk all the time' (Kelly: Interview: 23/3/11). Josie struggled much more with her emerging self and there appeared to be much more self-questioning than in other students' narratives as illustrated below:

I kind of thought, uhm, this is interesting. But what am I doing here Josie? What are you doing here? When I first came in, I thought oh it's alright, it's not that big, so when I first got here I was like, ugh, but then after a few months I felt yeah, it's alright, it's alright, you can get used to this sort of thing. (Josie: Interview: 22/2/11)

There is a sense in which Josie took small steps and constantly matched up her experiences with her understanding of her own identity. She did go on to describe the ambiguity of her social position- 'I'm not quite there yet' (Josie: Interview: 22/2/11)-further articulating a sense of dislocation in terms of understanding the disjuncture between her 'university' self and her 'outside university' self. Here, the notion of habitus clivé (Bourdieu, 2004; Reed-Danahay, 2005) is helpful in explaining the tension experienced by Josie as she attempted to align herself to both social groups. Josie also goes on to explain that she does not feel that going to university was the right decision for her. This could indicate the extent to which she was not able to fully align her primary habitus with that of the institution:

It was probably the wrong choice for me; I don't feel like I enjoy it and still don't feel at home after 3 years. I would not recommend university to my friends unless they were sure they knew what they wanted to do in life, this has left me more confused than when I came. The idea of coming to university is better than it actually is (for me). (Josie: e-mail communication: 22/1/11) 


\section{J. Social Sci., 8 (2): 126-134, 2012}

Whilst theoretical social positioning would suggest that Josie should be able to align herself with the habitus of a post-1992 institution, this was never achieved. Reflecting in the final year of her course, she illustrates how she has reconciled herself to being 'different':

In year one I was more focussed on fitting in and making friends and worried what people would think of me and if they would judge me. Now I have accepted that I am different and I don't care what people think or might think about me. The big change is me being ok with not fitting in. (Josie: e-mail communication: 22/1/11)

The social arena is one way in which students begin to construct their HE identity-the other is through their academic studies. Molly for example states, 'the feelings I still get about being at university is that I still doubt if I am 'clever' enough to be here' (Molly: e-mail communication: 15/1/11). Lucy also reflects on how she felt about academic work stating that she was 'worried that the work would be too hard' (Lucy: email communication: 10/1/11). Such questioning of position is consistent across the sample although it is a position that goes unarticulated with academic tutors. Bourdieu and Passeron (1977) offer insights into this by exploring legitimacy of position-should students admit that they do not understand the academic aspect of university life, their occupation of a student place becomes questionable for the students in this study, this impact upon their feelings of confidence about whether they deserve to be at university. This becomes even more open to scrutiny in Year 3, as students acknowledge an increased demand in the requirements of academic tasks. Kelly, for example states about the final year:

I don't like this year because there's too much pressure. If it was designed differently so that the second year was say $40 \%$ and the third year was $60 \%$ I think I would have pulled my finger out of my backside a bit quicker and got on with doing, then I would have got my work up to the academic standard then rather than having to make a massive leap now because I just thought, it's only $20 \%$, I just need to pass it, whereas actually if I had got a good grade then it could have taken the pressure off a bit now (Kelly: Interview: 23/3/11).

Whilst it is evident that students found the demands of academic work challenging at times, their sense of belonging to the institution clearly developed over the three years of their undergraduate programme. With the exception of Josie (as discussed above), all students involved in the research detailed the ways in which they had constructed their identities as they became increasingly acculturated within the institution. This process involved becoming familiar with the particular institutional habitus and finding ways of adapting to its practices that both structure and are structured by the student body.

\section{CONCLUSION}

There are initial indications that work around widening participation students' identity could tell us something about the ways in which such young people transform throughout their undergraduate programme and the ways in which they adapt to the context of university life. The process of adaptation is not problem free despite the idea that 'going to higher education [has] become far more normalized than it once would have been' (Thomas and Quinn, 2007). The deliberation of the tension between 'transformation' and 'transgression' is therefore extremely complex. This complexity is further emphasised by the fuzzy boundaries of what constitutes a widening participation student. Exploring this issue from a Bourdieuian perspective would suggest that students from neighbourhoods with high IMD rank scores would establish a fit with HE because assumptions are made about the levels and relative weighting of the various forms of capital they possess (Bourdieu, 1986). However, it is clear that this form of analysis may not be adequate in identifying those who appear to be 'fish out of water' (Reay et al., 2010) particularly given that the majority of students in this study found ways in which to establish a sense of fit with the institution. In terms of considering this as an act of transgression from a family based habitus, it is evident from this study that this is not the case as the majority of students in fact felt supported by their families. As such, the families became an important component within the process of habitus adaptation. This could be representative of generational habitus shifts (Byrom, 2010) where there is increased acceptance of HE participation amongst families without a previous history of education at that level.

It is evident from research (Reay, 2001) that institutional habituses are by dint of their collective nature are less fluid than individual habitus' which places the focus on students to adapt to their context. This has implications in post-1992 institutions where the lack of alignment with the institution could lead to issues of progression and retention. This study is timely given the recent move to increase tuition fees from 2012 where it is expected that student expectations of their HE 'offer' may change and the influence of the institution in identity trans/formation will become critical in processes of social mobility. 


\section{J. Social Sci., 8 (2): 126-134, 2012}

\section{REFERENCES}

Agasisti, T., 2009. Towards 'lisbon objectives': Economic determinants of participation rates in university education: An empirical analysis in 14 European countries. Higher Educ. Q., 63: 287-307. DOI: $10.1111 / \mathrm{j} .1468-2273.2008 .00416 . \mathrm{X}$

Archer, L. and M. Hutchings, 2000. 'Bettering yourself'? Discourses of risk, cost and benefit in ethnically diverse, young working-class, nonparticipants' constructions of higher education. Brit. J. Soc. Educ., 21: 555-574. DOI: 10.1080/713655373

Archer, L., M. Hutchings and A. Ross, 2003. Social Class and Higher Education. Higher Education and Social Class: Issues of Exclusion and Inclusion. 1st Edn., Routledge, London, ISBN: 10: 0415276438, pp: 277.

Ball, S.J., 2003. Class Strategies and the Education Market: the Middle Classes and Social Advantage. 1st Edn., Routledge Falmer, London, ISBN-10: 0415272777, pp: 213.

BERA, 2004. Revised Ethical Guidelines for Educational Research. British Educational Research Association.

Blanden, J. and S. Machin, 2004. Educational inequality and the expansion of UK higher education. Scott. J. Political Econ., 51: 230-249.

Bourdieu, P. and L.C. Clough, 1996. The State Nobility: Elite Schools in the Field of Power. 1st Edn., Stanford University Press, Cambridge, ISBN10: 0804717788, pp: 475.

Bourdieu, P. and L.J.D. Wacquant, 1992. An Invitation to Reflexive Sociology. 1st Edn., University of Chicago Press, Chicago, ISBN-10: 0226067416, pp: 332 .

Bourdieu, P., 1984. Distinction: A Social Critique of the Judgement of Taste. 1st Edn., Harvard University Press, Cambridge, ISBN-10: 0674212770, pp: 613.

Bourdieu, P., 1990a. The Logic of Practice. 1st Edn., Stanford University Press, Stanford, ISBN-10: 0804720118, pp: 333.

Bourdieu, P., 1990b. In Other Words: Essays towards a Reflexive Sociology. 1st Edn., Stanford University Press, Stanford, ISBN-10: 0804717257, pp: 223.

Bourdieu, P., 1997. The Forms of Capital. In: Education, Culture, Economy and Society, Halsey, Lauder, A.H. H., P. Brown and A.S. Wells, (Eds.). Oxford University Press, Oxford, pp: 46-58.

Bourdieu, P., 1998. Practical Reason: On the Theory of Action. 1st Edn., Stanford University Press, Stanford, ISBN-10: 0804733635, pp: 153.
Bourdieu, P., 1999. The Contradictions of Inheritance. In: The Weight of the World: Social Suffering in Contemporary Society, In: Bourdieu, P., A. Accardo and G. Balazs, (Eds.). Stanford University Press, Stanford, pp: 507-513.

Bourdieu, P., J.C. Passeron, R. Nice and T. Bottomore, 1977. Reproduction in Education, Society and Culture. 1st Edn., Sage Publications, London, pp: 254.

Byrom, T., 2009. I don't want to go to a crummy little university': Social class, higher education choice and the paradox of widening participation. Improving Schools, 12: 209-224. DOI: 10.1177/1365480209348819

Byrom, T., 2010. The Dream of Social Flying: Widening Participation in Higher Education. 1st Edn., LAP Lambert Academic Publishing, Saarbrucken, ISBN: 10: 3838336690, pp: 484.

Chowdry, H., C. Crawford, L. Dearden, A. Goodman and A. Vignoles, 2008. Widening Participation in Higher Education: Analysis using Linked Administrative Data. 1st Edn., The Institute for Fiscal Studies, London, ISBN-10: 9780102954203.

Healy, J., 2006. Locality matters: Ethnic segregation and community conflict-the experience of protestant girls in belfast. Children Society, 20: 105-115. DOI: 10.1111/j.1099-0860.2006.00018.x

Holloway, G., 1997. Finding a Voice: On Becoming a Working-Class Feminist Academic. In: Class Matters: 'Working-Class' Women's Perspectives on Social Class, Mahoney, P. and C. Zmroczek, (Eds.). Taylor and Francis, London, pp: 190-205.

Leathwood, C. and P. O'Connell, 2003. 'It's a struggle': The construction of the 'new student' in higher education J. Educ. Policy, 18: 597-615. DOI: 10.1080/0268093032000145863

Leathwood, C., 2006. Accessing Higher Education: Policy, Practice and Equity in Widening Participation in England. In: Beyond Mass Higher Education: Building on Experience, McNay, I. (Ed.). McGraw-Hill International, Maidenhead, ISBN-10: 0335218571, pp: 17-25.

Lightfoot, N., 2009. A view from the other side: Interpretations of widening participation by a post1992 university. Improving Schools, 12: 196-208. DOI: $10.1177 / 1365480209342618$

Mahony, P. and C. Zmroczek, 1997. Class matters: 'working-class' women's perspectives on social class. 1st Edn., Taylor and Francis, ISBN-10: 0748405410, pp: 210. 
McNay, I., 2006. Beyond Mass Higher Education: Building on Experience. 1st Edn., McGraw-Hill International, Maidenhead, ISBN-10: 0335218571, pp: 240.

Nash, R., 1999. Bourdieu, 'Habitus' and educational research: Is it all worth the candle?' Brit. J. Sociol. Educ., 20: 175-281.

Parr, J., 1997. Women, Education and Class: The Relationship between Class Background and Research. In: Class Matters: 'Working-Class' Women's Perspectives on Social Class, Mahony, P. and C. Zmroczek (Eds.). Taylor and Francis, London, pp: 30-43

Platt, L., 2011. Understanding Inequalities: Stratification and Difference. 1st Edn., John Wiley and Sons, Cambridge, ISBN-10: 074564175X, pp: 204.

Power, S., 2003. Education and the Middle Class. 1st Edn., Open University Press, Buckingham, ISBN-10: 0335205550, pp: 175.

Reay, D., 2001. Finding or losing yourself?: Workingclass relationships to education. J. Educ. Policy, 16: 333-346. DOI: 10.1080/02680930110054335

Reay, D., 2004. 'It's all becoming a habitus': Beyond the habitual use of habitus in educational research. Brit. J. Sociol. Educ., 25: 431-444. DOI: org/10.1080/0142569042000236934
Reay, D., G. Crozier and J.Clayton, 2010. Fitting in' or 'standing out': Working-class students in UK higher Education. Brit. Educ. Res. J., 36: 107-124. DOI: 10.1080/01411920902878925

Reay, D., M.E. David and S.J. Ball, 2005. Degrees of Choice: Social Class, Race, Gender and Higher Education. 1st Edn., Trentham Books, Stoke-onTrent, ISBN-10: 1858563305, pp: 180.

Reed-Danahay, D., 2005. Locating Bourdieu. 4th Edn., Indiana University Press, Bloomington, ISBN-10: 0253345081, pp: 208.

Rose, M., 1989. Lives on the Boundary: A moving Account of the Struggles and Achievements of America's Educationally Underprepared. 1st Edn., Penguin Books, New York:, ISBN: 10: 0140124039, pp: 255.

Skeggs, B., 1997. Formations of Class and Gender. 1st Edn., SAGE, London, ISBN: 10: 0761955119, pp: 192.

Thomas, E. and J. Quinn, 2007. First Generation Entry Into Higher Education: An International Study. 1st Edn., McGraw-Hill International, Maidenhead, ISBN: 10: 0335217907, pp: 150.

Walkerdine, V., H. Lucey and J. Melody, 2001. Growing Up Girl: Psychosocial Explorations of Gender and Class. 1st Edn., New York University Press, New York, ISBN-10: 0814793835, pp: 240. 